\title{
Enhancing Writing Performance of Iranian EFL University Students in the Light of Using Computer Assisted Language Learning
}

\author{
Mustapha Hajebi ${ }^{1}$ \\ ${ }^{1}$ Department of Education, Bandar Abbas, Iran \\ Correspondence: Mustapha Hajebi, Department of Education, Bandar Abbas, Iran
}

Received: October 22, 2018; Accepted: November 12, 2018; Published: December 5, 2018

\begin{abstract}
The purpose of this research is to improve the performance of Iranian EFL students writing process model based on technology to see computer software checked the grammar, punctuation, spelling and the performance of students. So there is in need of different conditions to design protocols for using computer assisted language learning to improve students' performance. A quantitative method including pre- test and post -test followed in this study. The study lasted for four weeks with naturalistic use of computer software in the writing instruction of experimental group to check the performance of students based on using computer assisted language learning. The present study involves various techniques in writing performance in contrast with other traditional methods. Computer assisted language learning was employed to compare and assess the writing performance. The results of the study support the idea that word processors improve the EFL learners' writing mechanism. Computer assisted language learning gives best path for the writing performance of students and also decreases mistakes in writings. This research provides recommendable performance for EFL learners, EFL teachers to adopt the technique in their classes to advance their students' language learning. Therefore, a comparison of the results after the next course cycle will then allow to impose the effects of enhancing writing performance, which would not be possible without using computer assisted language learning approach.
\end{abstract}

Keywords: E-Learning, communication technologies, CALL, writing skill, EFL learning, proficiency

\section{Introduction}

Abott, G., \& Wingard (1981) claimed that writing is a productive skill, although it is difficult. This difficulty lies in how to produce functional sentences which comprise a coherent text. Some CALL researchers believe that the majority of the EFL students in the schools and private institutes attempt to enhance their writing skill, but students never achieve to the satisfactory levels and they cannot write even simple texts. It is believed that one of the important problems is the methods of teaching in Iran (Baleghizadeh, S., \& Oladrostam, E. 2011).

Computer assisted language learning creates a flexible, enjoyable, low anxiety and interactive language learning environment for language students. With the aid of the internet, multimedia technology and computerized devices, EFL students can increase their exposure to the target language at any time from any location. Moreover, CALL has become an important means of promoting autonomous language learners, increasing participation and motivation (Baleghizadeh, S, \& Oladrostam, E. 2011), developing innovative and authentic language learning materials and building the teacher-learner and learner-learner communication (Zeng, G., \& Takatsuka, S. 2009).

Many researchers claim the importance of CALL. They believe that using CALL can be more serviceable than using the traditional methods. e.g. (Alsouki, 2001, Pattern \& Cadienno, 1993, Aweis 1994, Christopher, 1995, Nagata, 1996, Nutta, 2001, Lin \& Chin 2007, Abu Seileek, 2004, Al- Qumoul, 2005, Bataineh, Ruba \& Bani Hani, Nedal 2011, Hajebi, M. Fahandezh, F., Tahei, S., \& Salari, H. (2018).

Based on Al- Haq and Al- Sobh (2010), writing is "an important communicative language skill” (p.189). In their view, "it is an activity that requires a mental effort to 'think out' the sentences and the ways of joining them to be meaningful and communicative" (p.189). In fact, "writing development involves changes that occur in children's strategic behavior, knowledge, and motivation" (Harris, Graham \& Mason, 2006, p.295). Usually this skill is taught with the aim of developing students' skill in learning writing in higher education or at work. "There is no doubt that writing is the most difficult skill for second language learners to master" (Aminzadeh \& Molaesmaeli, 2009, p.59). According to Yunus, Salehi and Nordin (2012), "of all the four language skills, ESL learners often find writing a daunting task owing to its complexity" (p.138). 
Learner problems with most of the time result in unfamiliarity of students with academic writing or the wrong techniques of teachers in teaching writing skills (Rankin-Brown, 2006). But according to Whiteman (1981), "students are weak in writing because teachers concentrate on teaching grammar, spelling drills, and punctuation rather than involving students in writing practice" (cited in Al-Haq \& Al-Sobh,2010, p.190). In modern countries the use of CALL in education has become a usual matter because of the range of development information and communications technology (Serin, 2011).

The current study is important because it can shed more light on the effectiveness of computer assisted language learning, in general, and computer software in particular on speeding up foreign language writing skills learning. Moreover, this study suggests CALL as an English pedagogical tool for learning writing skills for EFL students. The aim of this research is to explore significant statistical differences between experimental and control group scores of students in the respect of the English writing test due to using CALL technology in teaching writing skill and traditional method.

\subsection{Research Hypothesis}

Furthermore, the current study aims to discuss the following hypothesis:

1. CALL has impact on the writing performance of Iranian EFL university students

2. There are statistical significance differences between the impact of CALL and traditional method regarding the writing performance of Iranian EFL university EFL university students

\section{Methodology}

A quasi-experimental research including pre- test and post -test followed in this study. The study lasted for four weeks with naturalistic use of computer software in the writing instruction of the experimental group.

An original population of $74 \mathrm{EFL}$ students volunteer was selected to participate in this study. A proficiency (TOEFL) test was administered to homogenize the students. The researcher divided participants based on their choice to work with the software into experimental (20female and 17male) and control (20 male and 17 female) groups.

\subsection{Instruments}

\subsubsection{Placement Test}

To homogenize students based on their level of proficiency, a language proficiency TOEFL test was administered. Those students who score fell one standard deviation below and above the mean were chosen as valid sample of this study and assigned to experimental and control group based on their choice to work with the Software.

Both groups were pretested on their writing knowledge prior to the study and after finishing the treatment were post tested to see the effect of CALL on their writing performance. The same test also was used as post-test at the end of treatment. Before any instruction one essay writing was administered to 25 students for the purposes of the pilot study.

\subsubsection{Instructional Ginger and Word Software}

Ginger software can correct grammar and spelling mistakes. It has translator and comprehensive dictionary. Access to contextual synonyms and definitions can help learners to find appropriate words in writing and increase their vocabulary. It can be used at the same time with office 2010 software to check grammar and spelling errors.

\subsection{Procedure}

The researcher illustrated the instruction of the program to participants how to use the software in their computers. In order to accomplish its goals, students divided into two groups. Experimental group worked with a computer software (Ginger and office) and access to the Internet or a teacher feedback and the control group received the traditional instructions.

Both groups initially took the pretest. The experimental group received their writing instruction through computer software and the feedback presented through the Ginger software. The teacher of both groups was the same and she used the textbook practical writing and reading by Edward Bailey. The researcher assigned five written tasks and asked all the participants to write complete, coherent essays during ten weeks. In addition, a week later, the experimental group sent their individual writings to the instructor to be scored. Also, the researcher checked their problems by giving comments on their essays. 


\section{Results}

As set forth in Table 1, the inter-rater reliability index for writing test which was used in this study was assessed 0.84 using Pearson correlation coefficient. In fact, two raters scored the essay papers and Pearson correlation coefficient was computed between these two sets of scores. Thus, the instrument used in this study has acceptable reliability value.

Table 1. Reliability Statistics of the Instruments

\begin{tabular}{llll}
\hline Instrument & No. of items & Pearson Correlation & Sig. 2-tailed \\
\hline Writing Test & 1 & 0.84 & .000 \\
\hline
\end{tabular}

\section{Testing Assumptions}

Before one determines to use parametric tests, four assumptions (i.e., interval data, independence of subjects, normality and homogeneity of variances) should be met (Field, 2009). The first assumption is not violated as the present data are measured on an interval scale. Moreover, as (6) posits, the assumption of independence of subjects is met when "the performance of any given individual is independent of the performance of other individuals". Besides, the third assumption is about the normality of the data which was examined through of one-sample Kolmogorov- Smirnov test, the results of which are laid out in Table 2.

Table 2. One-Sample Kolmogorov-Smirnov Test of Normality for Writing Scores (Pre-test \& post-test)

\begin{tabular}{lllll}
\hline Test & Group & $\mathrm{N}$ & Kolmogorov-Smirnov Z & Sig. (2-tailed) \\
\hline \multirow{2}{*}{ Pre-test } & Experimental & 37 & .704 & .705 \\
& Control & 37 & .569 & .903 \\
\hline \multirow{2}{*}{ Post-test } & Experimental & 37 & .956 & .297 \\
\cline { 2 - 5 } & Control & 37 & .680 & .745 \\
\hline
\end{tabular}

Table 2 notifies that the two sets of writing pre-test scores for both experimental group $(p=.70, p>.05)$ and control group $(p=.90, p>.05)$ enjoy the normality assumption. Further, the table reflects that the two sets of writing post-test scores for both experimental group $(p=.29, p>.05)$ and control group $(p=.74, p>.05)$ are normally distributed. Hence, we were justified to apply independent sample $t$-test, which is a parametric statistical test.

Table 3. Independent Samples Test for Two Groups' on the Writing Pre-test

\begin{tabular}{lllllll}
\hline \multirow{2}{*}{ Levene's Test for Variances } & \multicolumn{5}{l}{ T-test for Means } \\
\cline { 2 - 7 } & \multicolumn{1}{l}{ Factor } & Sig. & $t$ & $d f$ & Sig. (2-tailed) & Mean Diff. \\
\hline $\begin{array}{l}\text { Equal variances assumed } \\
\begin{array}{l}\text { Equal variances not } \\
\text { assumed }\end{array}\end{array}$ & .167 & .631 & 78 & .530 & .500 \\
\hline
\end{tabular}

According to Table 3, $t$-value and significance level $(t(78)=.63, p=.53, p>.05)$ are indicative of no statistically significant difference in writing scores for experimental $(\bar{x}=16.81)$ and control $(\bar{x}=16.31)$ groups. In addition, the $t$-observed was below the $t$-critical (1.98); hence, we it was discovered that the students in the two groups were almost in the same level of writing ability before the course starts. 
Table 4. Independent Samples Test for Two Groups' Scores on the Writing Post-test

\begin{tabular}{|c|c|c|c|c|c|c|}
\hline \multicolumn{3}{|c|}{ Levene's Test for Variances } & \multicolumn{4}{|c|}{ T-test for Means } \\
\hline Factor & $F$ & Sig. & $t$ & $d f$ & Sig.(2-tailed) & Mean Diff. \\
\hline $\begin{array}{l}\text { Equal } \\
\text { variances } \\
\text { assumed }\end{array}$ & 2.161 & .146 & 3.121 & 78 & .003 & 1.850 \\
\hline $\begin{array}{l}\text { Equal } \\
\text { variances } \\
\text { assumed }\end{array}$ & & & 3.121 & 75.162 & .003 & 1.850 \\
\hline
\end{tabular}

Independent $t$-test (Table 4) detected a statistically significant difference $(t(78)=3.12, p=.003, p<.05)$ in writing measures for experimental group $(\bar{x}=25.17)$ and control group $(\bar{x}=23.32)$, in which the $t$-observed reached higher than the $t$-critical of 1.98. Therefore, it could claim that CALL improves the writing performance of Iranian EFL university students.

For further exploration, paired samples $t$-test was performed to compare the pre-test and post-test writing measures in each group, the results of which are shown in Table 5.

Table 5. Paired Samples T-test for Pre-test and Post-test of Writing Performance in Two Groups

\begin{tabular}{|c|c|c|c|c|c|c|c|}
\hline & $\begin{array}{l}\text { Gain } \\
\text { Score }\end{array}$ & $S D$ & $\begin{array}{l}95 \% \text { Confidence } \\
\text { Difference }\end{array}$ & Interval of the & $t$ & $d f$ & $\begin{array}{l}\text { Sig.(2- } \\
\text { tailed }\end{array}$ \\
\hline Group & & & Lower & Upper & & & \\
\hline Experimental & 8.362 & 2.423 & 7.587 & 9.137 & 21.827 & 37 & .000 \\
\hline Control & 7.012 & 2.983 & 6.058 & 7.966 & 14.863 & 37 & .000 \\
\hline
\end{tabular}

As seen in Table 5, paired samples $t$-test indicated that there was a statistically significant increase $(t(39)=21.82$, $p=.000, p<.05)$ in writing scores from pre-test $(\bar{x}=16.81, S D=3.15)$ to post-test $(\bar{x}=25.17, S D=2.38)$ in the experimental group. In fact, gained score in writing was 8.36 (out of 30 ) with a $.95 \%$ confidence interval ranging from 7.587 to 9.13 . Similarly, $t$-test detected a statistically significant increase $(t(39)=14.86, p=.000, p<.05)$ in writing measures from pre-test $(\bar{x}=16.31, S D=3.89)$ to post-test $(\bar{x}=23.32, S D=2.89)$ in the control group. In fact gained score was 7.01 (out of 30 ) with a $.95 \%$ confidence interval ranging from 6.05 to 7.96 . In general, the two groups had considerable improvement in the writing performance, but gained score in the experimental group (8.36/30) was a much higher than the control group (7.01/30).

\section{Discussion}

Writing played an important role in education as well as a fundamental skill in teaching and learning. This paper was an attempt to see if there was any difference in the performance of students' writing when computer software checked the grammar, punctuation and spelling compared to the performance of those whose hand-written assignments were checked by the teacher. It could be claimed that using computer software has affected the students' performance in the experimental group. Therefore, the method used in this study could be more effective in English Writing. If the learners were well-guided in the CALL classes, learning could flow easily at home and in front of their computers.

The findings of this study would be useful for instructors in employing CALL approach in learning strategies as an effective method in teaching writing. In addition policy makers should change the educational system by computerized programs in the way of improving both teaching and learning the English language by CALL, because learners may train more with the help of Education and Technology together.

\section{References}

Abott, G., \& Wingard, P. (1981). The teaching of English as an international language: A practical guide. London: Collins.

Baleghizadeh, S., \& Oladrostam, E. (2011). The effect of mobile assisted language learning (MALL) on grammatical accuracy of EFL students. MEXTESOL Journal, 34(2), 1-10. 
Bataineh, R., \& Baniabdelrahman, A. (2006). Jordanian EFL students' perceptions of their computer literacy: An exploratory case study. International Journal of Education and Development Using ICT, 2(2).

Hajebi, M., Taheri, S., Fahandezh, F., \& Salari, H. (2018). The role of web-based language teaching on vocabulary retention of adult pre- intermediate EFL learners. Journal of Language Teaching and Research, 9(2), 372378. https://doi.org/10.17507/jltr.0902.20

Lee, L. (2005). Using web-based instruction to promote active learning: Learners' perspectives. CALICO Journal, 23(1), 139-156. https://doi.org/10.1558/cj.v23i1.139-156

Leki, I . (1991). Teaching second language writing: Where we seem to be. English Teaching Forum, 29(2\&3), 811.

Lin, H., \& Chin, T. (2007). Reading authentic EFL text using visualization and advanced organizers in a multimedia learning environment. Language Learning and Technology, 11(3), 83-106.

Mohammadi, N., Gorijan, B., \& Alipour, M. (2012). Effects of computer assisted language learning (CALL) approach on EFL learners' descriptive essay writing: The evaluation of computer grammar and spelling checker software. Advances in Digital Multimedia, 1(2), 2166-2916.

Raby, F. (2007). A triangular approach to motivation in computer assisted autonomous language learning (CAALL). ReCALL, 19(2), 181-201. https://doi.org/10.1017/S0958344007000626

Yunus, M. M., Salehi, H., \& Nordin, N. (2012). ESL pre-service teachers' perceptions on the use of paragraph punch in teaching writing. English Language Teaching, 5(10), 138-147. https://doi.org/10.5539/elt.v5n10p138

Zeng, G., \& Takatsuka, S. (2009). Text-based peer-peer collaborative dialogue in a computer-mediated learning environment in the EFL context. System, 37(3), 434-446. https://doi.org/10.1016/j.system.2009.01.003

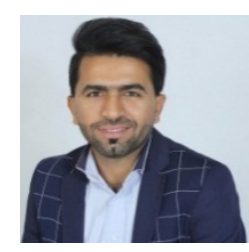

Mustapha Hajebi is an English language teacher in Department of Education, Bandar Abbas, Iran. He finished his undergraduate studies at Kharazmi University, majoring in TEFL. He continued his graduate studies at Islamic Azad University of Bandar Abbas, where he got his M.A degree in TEFL. His research interests include: Second Language Teaching, Applied ELT, Emotioncy, Speaking, Intelligence and Memory, Language Psychology, Collocations and Educational Technology

\section{Copyrights}

Copyright for this article is retained by the author(s), with first publication rights granted to the journal.

This is an open-access article distributed under the terms and conditions of the Creative Commons Attribution license (http://creativecommons.org/licenses/by/4.0/). 